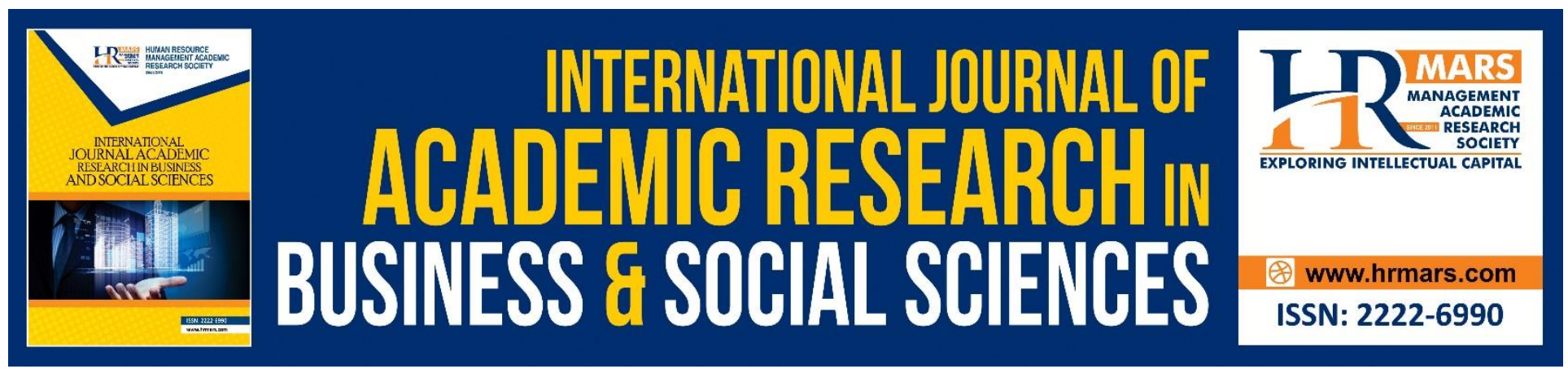

\title{
Tax Compliance: Impact of Employee Internal Factors, Moderated by Tax Uncertainty
}

Deden Tarmidi

To Link this Article: http://dx.doi.org/10.6007/IJARBSS/v9-i5/5859

DOI: $10.6007 /$ IJARBSS/v9-i5/5859

Received: 30 March 2019, Revised: 22 April 2019, Accepted: 12 May 2019

Published Online: 28 May 2019

In-Text Citation: (Tarmidi, 2019)

To Cite this Article: Tarmidi, D. (2019). Tax Compliance: Impact of Employee Internal Factors, Moderated by Tax Uncertainty. International Journal of Academic Research Business and Social Sciences, 9(5), 294-304.

Copyright: (C) 2019 The Author(s)

Published by Human Resource Management Academic Research Society (www.hrmars.com)

This article is published under the Creative Commons Attribution (CC BY 4.0) license. Anyone may reproduce, distribute, translate and create derivative works of this article (for both commercial and non-commercial purposes), subject to full attribution to the original publication and authors. The full terms of this license may be seen at: http://creativecommons.org/licences/by/4.0/legalcode

Vol. 9, No. 5, 2019, Pg. 294 - 304

http://hrmars.com/index.php/pages/detail/IJARBSS

JOURNAL HOMEPAGE

Full Terms \& Conditions of access and use can be found at http://hrmars.com/index.php/pages/detail/publication-ethics 


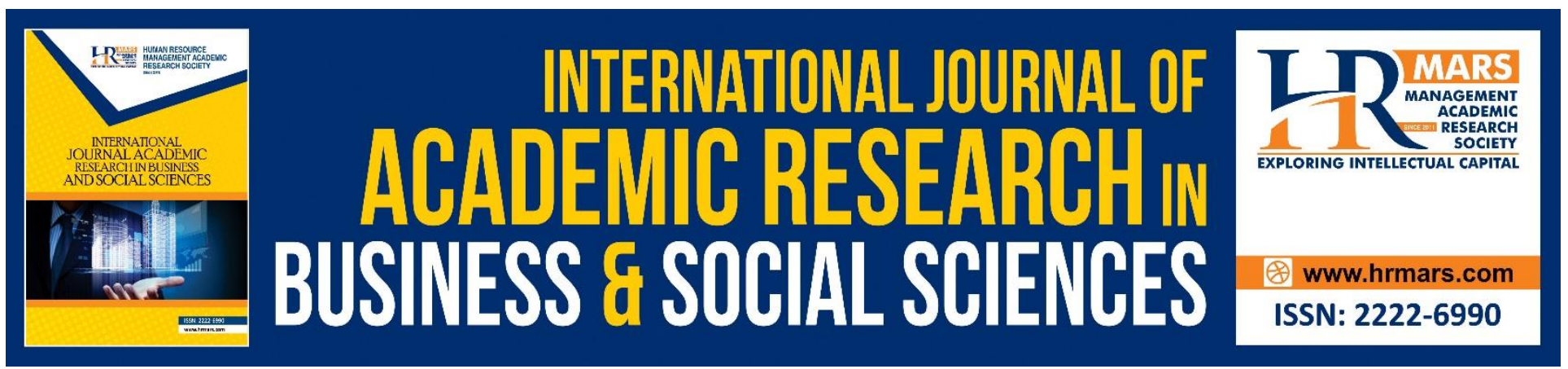

\title{
Tax Compliance: Impact of Employee Internal Factors, Moderated by Tax Uncertainty
}

\author{
Deden Tarmidi \\ Faculty of Economic and Business, Universitas Mercu Buana, \\ Email: deden.tarmidi@mercubuana.ac.id
}

\begin{abstract}
Tax is the biggest revenue for developing countries including Indonesia, but the level of tax compliance is still low. This study aims to determine the impact of internal tax accountant factors as taxation PIC in the corporate and to find out the moderation impact from tax uncertainty. 100 Undergraduate and postgraduate accounting students working as tax accountants in the company were sampled in this study by convenience sampling method. Using the Structure Equation Model (SEM) approach with smartPLS software, it was found that understanding and ethics had a significant impact on tax compliance, while the ability did not significantly impact. In the moderation analysis, it was found that the impact of moderation from tax uncertainty weakened the impact of understanding and ethics on tax compliance, while on ability only interacted. These findings provide 2 implications, for companies in recruiting employees who will be used as tax accountant PIC companies in order to consider the understanding and ethics of prospective employees, and the other is for the directorate general of taxes to pay more attention to the tax provisions issued so as not to burden taxpayers so that the perception of tax uncertainty arises which causes a decrease in tax compliance.
\end{abstract}

Keywords: Understanding, Ability, Ethics, Tax Uncertainty, Tax Compliance

\section{Introduction}

Tax revenue has an important role in the development of a country, including Indonesia. Even though the tax is a compulsion towards the people who already have subjective and objective tax obligations, but indirectly their use is enjoyed by every member of society in various forms of public services and improving the economy of the community. However, the level of tax compliance in Indonesia is still low, even though tax compliance is important so that state revenues from taxes can be optimal (Boll, 2013).

With the self-assessment system used in Indonesian taxation, taxpayers are given the authority to calculate, pay and report their taxes, including companies represented by tax professionals as employees. The system forces taxpayers to have their respective capabilities in carrying out their tax obligations. In the $Y$ theory, which was coined by Gregor (1968) that individual internal factors can carry out their own activities according to organizational goals, tax accountants as employees in 
companies with different individuals are thought to have an influence on corporate tax compliance through their activities as well as good quality financial statements. (Call et al., 2017).

Besides social, structural and legal, some studies conclude that individual factors such as moral / ethics, age, gender, education level, marital status and religiosity of both taxpayers and tax authorities have to do with tax compliance and tax crime rates (Moeinadin, et al., 2014, Alasfour et al., 2016; Kasipillai et al., 2006 ; Downs and Stetson, 2014). Other individual factors that have an important influence in tax compliance are the knowledge or understanding of taxpayers on applicable tax provisions, in addition the ability to implement tax and accounting provisions in each company transaction is equally important (Tusubira and Nkote, 2013; Atawodi and Ojeka; 2012).

A profit-oriented organization certainly does everything possible to achieve the targeted profits, including in accounting and taxation activities. Applicable accounting standards must be followed so that the resulting financial statements are beneficial to stakeholders (Unegbu, 2014) but on the one hand they are related to income taxes that reduce profits (Tzovas, 2006). So some companies make different financial statements for accounting purposes with financial statements for tax purposes (Purina, 2015; Kirsch and Olsson, 2008) or do certain tricks so that the amount of tax payable is smaller (Nkuah, et al., 2015; Russel, 2014; Logan, 2011). The ability of employees to represent companies to carry out tax obligations has an impact on corporate tax burden and tax penalties (Lin and Zeng, 2017), as well as the level of corporate tax compliance.

In Tax Law No. 6 of 1983 as last amended to Law Number 16 of 2009, in Indonesia there are tax provisions regarding the expiration of billing for 5 years and can be added for another 5 years if evidence from third parties is found. Taxes calculated, paid and reported by tax payers will be certain for the next 10 years. And within that period if a Tax Assessment Letter or Tax Collection Letter is issued, then the tax expiration will be calculated from the beginning again for the next 5 years. This certainly makes legal uncertainty on tax reporting that has been carried out by taxpayers.

In business activities, the tax uncertainty certainly has an impact on tax savings and company profits (Brown, et al., 2017) and this is ultimately utilized by taxpayers to carry out tax avoidance to tax evasion (Huang, et al., 2017) because of distrust to State administrators including tax authorities (Kasper, et al., 2015).

The results of this study can help companies find tax staff in charge of taking care of corporate taxation so that the level of corporate tax compliance becomes good and avoid tax penalties that will harm the company in the future. Besides that, the advantages of this research is that it analyses the element of tax uncertainty in the taxpayer compliance process that can be important information and input for the government in determining tax policies. As explained in attribution theory that taxpayer compliance can be influenced by internal (tax staff) and external (tax policy).

\section{Literature Review}

\section{Theoretical Framework}

\section{Tax Compliance Theory}

Devos (2012) explains the Theory of Tax Compliance, which is divided into two approaches, namely: 1) Economic deterrence approach and 2) Psychological approach. Where in the economic deterrence approach an approach is taken by considering external factors such as tax information and systems, tax deductions by other parties, tax penalties, possible tax audits, and tax rates. While the 
psychological approach is carried out by considering the factors of individual taxpayers or employees of corporate taxpayers related to corporate taxation activities.

This study analyzes tax compliance with the psychological approach where it will be analyzed how individual factors, one of which is understanding tax provisions, tax management capabilities, the ability to present financial statements according to tax provisions and also the perception of tax accountants on tax uncertainty towards tax compliance. While tax compliance in this study is the fulfillment of tax obligations by taxpayers both formally, (procedure) and material (tax calculation).

\section{Attribution Theory}

In attribution, theory triggered by Fritz Heider (1958) internal (personal) factors and external (situational) factors are causes of a person's behavior and must be determined before observing a person's behavior. Weiner (1980) developed attribution theory in the world of education, which explains that attribution is a contemporary theory that influences the motivation of students. Weiner (1980) explains that there are 4 factors that influence attribution namely: skill or ability, task difficulty, effort or effort and luck, where skill and effort are internal factors that can be controlled by one's personal self, while task difficulty and luck are external factors which cannot be controlled. Spencer (1993) in the theory of competence explains that a person's success in doing something is influenced by his ability personally about what he does, so that by knowing the person's ability, it can be predicted how the work will be done. Whereas Benjamin S. Bloom as the originator of taxonomy bloom (1956) divides education into several parts including the cognitive domain, one of which is knowledge, which is the initial level in understanding.

In this study, where the individual factors of employees consisting of understanding, ability and ethics are some internal factors that are thought to affect an employee of tax accounting in the tax compliance of the company where he works.

\section{Conceptual Framework and Hypothesis Development Understanding on Tax Compliance}

The provisions of taxation and accounting standards that often change in line with the latest developments and the rapid economy require accountants to have an in-depth understanding of each applicable tax provision and accounting standards. Directorate of General Taxation sometime make a socialization to taxpayer when there a new regulation although limited moment and time, but that is important for increase knowledge and understanding of taxpayer and tax compliance (Andreas \& Safitri, 2015). Sarpingah et al. (2017) and Hardiningsih \& Nila (2011) in their research found that the knowledge of a taxpayer could influence awareness of tax compliance. Understanding of taxpayers is thought to have an effect on tax compliance.

H1. Understanding has a positive impact on tax compliance

\section{Ability on Tax Compliance}

Prabowo (2012) in his research on the ability and motivation of tax consultant office employees got the conclusion that a person's ability has a positive effect on his performance. And Bateman \& Snell $(2015 ; 18)$ explained that conceptual skills, human skills and technical skills should be owned by a 
INTERNATIONAL JOURNAL OF ACADEMIC RESEARCH IN BUSINESS AND SOCIAL SCIENCES Vol. 9, No. 5, May, 2019, E-ISSN: 2222-6990 ㄷ 2019 HRMARS

manager in his activities in this case also the tax accountant who is in charge of carrying out bookkeeping and preparing tax reports. So researchers have the following hypothesis:

H2. Ability has a positive effect on tax compliance

\section{Ethics and Tax Compliance}

In his research, Arestanti, et.al. (2016) concluded that someone who has a high perception of ethics will trigger the person in making ethical decisions. Likewise Hageman \& Fisher (2016), Field (2017), Arestanti, et al. (2016), Darmayasa \& Aneswari (2015), Trivedi et.al. (2005), Awang \& Amran (2014) and Tarmidi \& Waluyo (2014) in their study obtained results that ethics and attitudes have a greater influence than behavioral controls and audits on tax compliance.

Ethics is the principle of behavior possessed by a tax accountant in carrying out his duties in the field of bookkeeping and taxation, ethics is thought to be a control for tax accountants so that the activities carried out do not deviate from the applicable tax provisions. In accordance with the research of Reckers et al. (1994) that people who have ethics tend to avoid tax evasion and tend to adhere to applicable accounting standards and tax provisions. So researchers have the following hypothesis:

H3. Ethics has a positive effect on tax compliance

\section{Tax Uncertainty on Understanding, Ability, Ethics and Tax Compliance}

Tax is one of the burdens for the business world that will reduce profits, a number of tax burdens can make taxpayers carry out tax avoidance or tax evasion especially if there is tax uncertainty both in terms of time and other matters, it is suspected that it will negatively affect tax compliance because it occurs savings diversification (Brown et al., 2017; Bernasconi et al., 2015; Muehlbcaher et al., 2017). Huang et al. (2017) and Alm et al. (2017) found that uncertainty in taxes has a positive effect on tax avoidance and tax aggresively, which means a negative effect on tax compliance. In connection with internal factors which consist of understanding, ability and ethics, tax uncertainty is expected to weaken the influence of these internal factors on tax compliance. So the researcher has the following hypothesis:

H4a. Tax uncertainty weakens the impact of understanding on tax compliance

H4b. Tax uncertainty weakens the impact of ability on tax compliance

H4c. Tax uncertainty weakens the impact of ethics on tax compliance

\section{Methodology \\ Population and Sample}

This study is causality research to find effect of employee internal factors like understanding, skill and ethics on corporate tax compliance and also find moderating impact of tax uncertainty on employee internal factors and corporate tax compliance. 100 students of accounting bachelor and master degree who have a job as a tax accountant in corporate have been as unit analysis with convenience sampling methods.

\section{Operational Variable}

Tax compliance in this study measured by 4 indicators are 1) on time tax reporting, 2) financial report audited, 3) on time tax paying, and 4) no tax arrears who adopted based on Indonesia Minister of 
Finance Regulation number 39/PMK.03/2018. While tax uncertainty measurement developed from Alm (2014) is 1) complicated tax system, 2) changeable tax system, 3) complicated tax rate, and 4) changeable tax rate.

As an independent variable, measurement of PIC understanding adopted from Budi (2016) is 1) understanding of tax regulation, 2) understanding of tax implementation regulation, 3) understanding of basic accounting and practices, 4) understanding of updated accounting standards, and 5) understanding corporate business law. While ability measured by 1) tax paying plan, 2) tax reporting plan, 3) tax credit plan, 4) book's forex and tax's forex, 5) withholding tax and payable, 6) VAT and sales plan, 7) withholding tax and receivable, and 8) fiscal reconciliation are developed from Schermerhorn (2012). Measurement of ethics is adopted by Recker (1994) and Tarmidi \& Waluyo (2014) is 1) honest in recognition of expenses, 2) honest in tax calculation, 3) don't hide tax objects, and 4) consequences for negligence and deliberation in tax reporting.

\section{Hypothesis Testing Method}

Structure Equation Model (SEM) approach used in this study and software smart PLS version 3 used for analyzing the data. Outer loading amount and AVE used to validity analysis while Composite reliability and Cronbach's alpha used for reliability analysis. Amount of adjusted r-square and amount inner of each endogen variables on exogen variable and also moderation variable used for hypothesis analysis.

\section{Result}

\section{Characteristics Respondent}

In the first part of the questionnaire there five questions are age, gender, the grade of degree, job desk and detail job desk. Jobdesk and detail jobd esk for know that respondent who has job as a tax accountant in the corporate can be use as a unit analysis in this study. From 100 tax accountant as the respondent in this study $71 \%$ is female and $29 \%$ is male, while by the respondent in the range of age 21 upto $25 y o$ is highest and undergraduate of accounting also highest than post graduate of accounting.

\section{Descriptive Analysis}

Table 1

\begin{tabular}{lrl}
\hline \multicolumn{1}{c}{ Variable } & Mean & Std. Deviation \\
\hline \hline X1. Understanding & 3,4178 & 0,7870 \\
X2. Ability & 3,4444 & 0,9276 \\
X3. Ethics & 4,1511 & 0,8527 \\
Z. Tax Uncertainty & 2,5611 & 0,8791 \\
Y. Tax Compliance & 4,2778 & 0,9279 \\
\hline
\end{tabular}


INTERNATIONAL JOURNAL OF ACADEMIC RESEARCH IN BUSINESS AND SOCIAL SCIENCES Vol. 9, No. 5, May, 2019, E-ISSN: 2222-6990 (C) 2019 HRMARS

Table 1 shows that the amount of means in each variable is more than the amount of standard deviation, that mean this data is good and can continue analysis.

\section{Goodness of Fit Analysis}

Table 2

\begin{tabular}{|c|c|c|c|c|c|}
\hline Variable & $\begin{array}{l}\text { Loading } \\
\text { Factor }\end{array}$ & AVE & $\begin{array}{l}\text { Composite } \\
\text { Reliability }\end{array}$ & $\begin{array}{c}\text { Cronbach's } \\
\text { Alpha }\end{array}$ & $\begin{array}{l}\text { Adj. R- } \\
\text { square }\end{array}$ \\
\hline $\begin{array}{l}\text { Understanding } \\
\text { (Uns) }\end{array}$ & $\begin{array}{r}0,762- \\
0,877\end{array}$ & 0,677 & 0,913 & 0,888 & \\
\hline Ability (Ab) & $\begin{array}{r}0,735- \\
0,897\end{array}$ & 0,670 & 0,942 & 0,933 & \\
\hline Ethics (Et) & $\begin{array}{r}0,889- \\
0,938\end{array}$ & 0,849 & 0,966 & 0,956 & \\
\hline $\begin{array}{l}\text { Tax Uncertainty } \\
\text { (TUn) }\end{array}$ & $\begin{array}{r}0,796- \\
0,948\end{array}$ & 0,751 & 0,923 & 0,900 & \\
\hline Tax Compliance (TC) & $\begin{array}{r}0,788- \\
0,892\end{array}$ & 0,710 & 0,907 & 0,862 & 0,414 \\
\hline
\end{tabular}

Table 2 explained that the amount of loading factor each variable is more than 0,70 and AVE is more than 0,50 , then data is valid. Amount of composite reliability and cronbach's alpha is more than 0,70 , that explained data is reliable. With the amount of adjusted $r$-square is 0,414 explained that the model is good (Ghozali \& Latan, 2015, 76-77; Hair et al., 2012; Hair et al., 2011).

\section{Hypothesis Test}

Table 3

\begin{tabular}{|c|c|c|c|c|c|c|}
\hline $\begin{array}{l}\text { Direct } \\
\text { Impact }\end{array}$ & $\begin{array}{l}\text { Moderated } \\
\text { Impact }\end{array}$ & $\begin{array}{l}\text { Original } \\
\text { Estimate }\end{array}$ & $\begin{array}{c}\mathrm{t}- \\
\text { statistics }\end{array}$ & P Values & $\mathbf{H}$ & Result \\
\hline \multirow[t]{2}{*}{ "Uns -> TC } & & 0,406 & 3,361 & $0,001^{* *}$ & + & Accepted \\
\hline & $\begin{array}{l}\text { Uns * Tun > } \\
\text { TC }\end{array}$ & 0,036 & 0,268 & 0,789 & V & Accepted \\
\hline \multirow[t]{2}{*}{$A b \rightarrow T C$} & & 0,015 & 0,087 & 0,930 & + & Rejected \\
\hline & $\mathrm{Ab} * \mathrm{Tun}>\mathrm{TC}$ & 0,065 & 0,474 & 0,636 & V & Rejected \\
\hline \multirow[t]{2}{*}{ Et $\rightarrow$ TC } & & 0,435 & 2,694 & $0,007 * *$ & + & Accepted \\
\hline & Et $*$ Tun $>$ TC & $-0,382$ & 1,934 & $0,054^{*}$ & V & Accepted \\
\hline Tun $->$ TC & & 0,346 & 3,361 & $0,014 * *$ & + & Accepted \\
\hline \multicolumn{7}{|c|}{$\begin{array}{l}* * * \text { Significant at level } 10 \%, * * \text { Significant at level } 5 \% \text {, and } * * * \text { Significant at } \\
\text { level1\% }\end{array}$} \\
\hline
\end{tabular}


Based on table 3, can be looked than Understanding and Ethics have a positive impact on tax compliance while Ability is not. That mean hypothesis 1 and 3 are accepted while hypothesis 2 is rejected. For moderated analysis based on table 3 that tax uncertainty weakens understandings' and ethics impact on tax compliance while not on ability impact on tax compliance, that men hypothesis $4 \mathrm{a}$ and $4 \mathrm{c}$ are accepted and $4 \mathrm{~b}$ is rejected.

These results explain that when tax accountant as an employee of corporate has a good understanding of taxation then can applicate on the job and corporate can began to comply. Tax accountants' ethics also can increase tax corporate compliance, because with ethics tax accountant don't want to do anything contrary law. The result in line with Sarpingah et al. (2017), Hardiningsih \& Nila (2011), Trivedi et.al. (2005) and Tarmidi \& Waluyo (2014).

While results of ability are contrary to Prabowo (2012), these explained that when the ability of tax accountant is good, tax planning made for deductible tax paid and decrease compliance. Especially of tax uncertainty, these result in line with Brown et al., (2017) and Huang et al. (2017) find that tax uncertainty can weaken of tax compliance although not in ability impact on tax compliance.

\section{Conclusion}

Tax accountants' understanding and ethics as an employee of corporate have a significant impact on corporate tax compliance, while tax accountants' ability is not. Tax uncertainty weakens tax accountants' understanding and ethics affect corporate tax compliance but not weaken tax accountants' ability on tax corporate compliance.

With these results, companies can consider looking for tax staff who have good understanding and ethics so that the level of corporate tax compliance is good. Whereas the results that tax uncertainty can weaken the influence of understanding and ethics on tax compliance, the government needs to be careful in making rules so that taxpayers do not have a perception of the uncertainty of the tax.

\section{Implication and Limitation}

Some implication can be information for better applicated of tax compliance and some limitation in this study can be information for better future study:

1. For increase tax compliance, HRD in corporate can look for tax accountant has good understanding and great ethics Employees' ability is good for the tax planning but can decreased tax compliance corporate, so be careful in the employee managing.

2. For improve tax compliance in Indonesia, Regulator should not make policies that are complicated and do not change frequently so that taxpayers get legal certainty of tax payable.

3. Unit analysis in this study is tax accountant but in the organization top leader has the highest power and also in the tax compliance. Using the top leader as a unit analysis in the future study maybe can find a different result.

\section{Acknowledgment}

This study supported by the Faculty of Economic and Business and Research Center of Universitas Mercu Buana, I'm grateful for the supported from Dean, Rector, Research Center team and especially respondents in this study. 
INTERNATIONAL JOURNAL OF ACADEMIC RESEARCH IN BUSINESS AND SOCIAL SCIENCES

Vol. 9, No. 5, May, 2019, E-ISSN: 2222-6990 @ 2019 HRMARS

\section{References}

Alasfour, F., Samy, M., \& Bampton, R. (2016), The Determinants of Tax Morale and Tax Compliance: Evidence from Jordan, in (ed.) Advances in Taxation (Advances in Taxation, Volume 23) Emerald Group Publishing Limited, 125 - 171

Alm, J. (2014). Does an Uncertain Tax System Encourage "aggressive tax planning"?. Economic analysis and Policy, 44 (1), 30-38

Alm, J., Bernasconi, M., Laury, S., Lee D. \& Wallace, S. (2017). Culture. Compliance, and Confidentiality: Taxpayer Behavior in the United States and Italy. Journal of Economic Behavior \& Organization, 140, 176-196

Andreas, \& Savitri, E. (2015). The Effect of Tax Socialization, Tax Knowledge, Expediency of Tax ID Number and Service Quality on Tax Payers Compliance With Taxpayers Awareness as Mediating Variables. Procedia - Social and Behavioral Sciences, 211, 163 - 169

Arestanti, M., Herawati, N., \& Rahmawati, E. (2016). Faktor - Faktor Internal Individu dalam Pembuatan Keputusan Etis: Studi pada Konsultan Pajak di Kota Surabaya. Jurnal Akuntansi dan Investasi, 17 (2), 104-117

Atawodi, O., \& Ojeka, S. (2012). Factors That Affect Tax Compliance Among Small and Medium Enterprise (SMEs) in North Central Nigeria. International Journal of Business and Management, 7(12), 87-96

Awang, N. \& Amran, A. (2014). Ethics and Tax Compliance, in (ed.) Ethics, Governance and Corporate Crime: Challenges and Consequences (Developments in Corporate Governance and Responsibility, Volume 6). Emerald Group Publishing Limited, 105 - 113

Bernasconi, M., Levaggi R. \& Menoncin, F. (2015). Tax Evasion and Uncertainty in a Dynamic Context. Economics Letter, 126, 171-175

Bloom, B. S. (1956). Taxonomy of Educational Objectives: Handbook 1, Cognitive Domain. New York: David McKay

Boll, K. (2013). Mapping Tax Compliance Assemblages, Distributed Action and Practices: a New Way of Doing Tax Research. Critical Perspectives on Accounting, 25 (4-5), 293-303

Brown, D. C., Cederburg, S., \& O'Doherty, M. S. (2017). Tax Uncertainty and Retirement Savings Diversification. Journal of Financial Economics, 126(3), 689-712

Budi, P. (2016). Manajemen Pajak : Teori \& Aplikasi (Edisi 2). Jakarta : PT Pratama Indomitra Konsultan

Call, A., Campbell J., Dhaliwal D. \& Moon, J. J. (2017). Employee quality and financial reporting outcomes. Journal of Accounting and Economics, 64(1), 123-149

Devos, K. (2012). The Impact of Tax Professionals upon The Compliance Behavior of Australian Individual Taxpayer. Revenue Law Journal, 22(1), 31-56

Downs, A. \& Stetson, B. (2014). Economic and Non Economic Factor: an Analysis of Corporate Tax Compliance. Advance in Taxation (Advances in Taxation, Volume 23), Emerald Group Publishing Limited, 37-72

Field, H. (2017). Aggressive Tax Planning \& The Ethical Tax Lawyer. Virgina Tax Review, 36, 261-320.

Ghozali, I. \& Latan, H. (2015) Partial Last Squares: Konsep, Teknik dan Aplikasi Menggunakan

Program SmartPLS 3.0. Semarang: Universitas Diponegoro.

Heider, F. (1958). The Psychology of Interpersonal Relations. New York: Wiley 
INTERNATIONAL JOURNAL OF ACADEMIC RESEARCH IN BUSINESS AND SOCIAL SCIENCES Vol. 9, No. 5, May, 2019, E-ISSN: 2222-6990 ㄷ 2019 HRMARS

Huang, H., Sun, L. \& Zhang, J. (2017). Environmental Uncertainty and Tax Avoidance. Advance in Taxation (Advances in Taxation, Volume 24), Emerald Group Publishing Limited, 83-124

Kasper, M., Kogler, C. \& Kirchler, E. (2015). Tax Policy and the News: an Empirical Analysis of Taxpayers' Perceptions of Tax Related Media Coverage and Its Impact on Tax Compliance. Journal of behavioral and experimental economics, 54, 58-63

Kasipillai, J. \& Abdul-Jabbar, H. (2006). Gender and Ethnicity Diffrences in Tax Compliance. Asian Academy of Management Journal, 11(2), 73-88

Kirsch, H. \& Olsson, S. (2008). Financial Accounting and Tax Accounting: Germany and Sweden as Examples. Skattenytt, 746-757

Lin, H. \& Zeng, T. (2017). Information Asymmetry and Incentive Contracting with the Tax Department. Review of Accounting and Finance, 16(3), 385-402

Logan, D. (2011). Three Differences Between Tax and Book Accounting That Legilslators Need to Know. Tax Foundation, 277

Moeinadin, M., Heirany, F. \& Harandi, A. (2014). Identyfing the Effective Factors for the Improvement of Tax Compliance. International Journal of Academic Research in Accounting, Finance and Management Sciences, 4(1), 220-227

Muehlbcaher, S., Harti, B. \& Kirchler, E. (2017). Mental Accounting and Tax Compliance: Experimental Evidence for the Effect if Mental Segregation of Tax Due and Revenue on Compliance. Public finance review, 45(1), 118-139

Nkuah, J., Frederick, A. \& Asamoah, K. (2015). The Correlation Between Accounting System of Small and Micro Enterprises and Tax Revenue Assessment in Ghana. Journal of education and elearning research, 2(1), 1-12

Purina, M. (2015). Tax Accounting in the Russian Federation. Procedia Economics and Finance, 25, 127-133

Reckers, P., Sanders, D. \& Roark, S. (1994). The Influence of Ethical Attitudes on Taxpayer

Compliance. National Tax Journal. 47(4), 825-836

Russel, D. (2014). Corporate Sustainability: Accounting Standards and Tax by Design. Social Responsibility Journal, 10(3), 386-398

Sarpingah, S., Sormin, F. \& Handayani, R. (2017). Influence of Taxation Knowledge and Socialization of Implementation PP.46 Year 2013 on Tax Compliance fo Certain WPOP Small and Medium Business (UMKM) Owner (Case Study in KPP Pratama Cengkareng, West Jakarta). Research Journal of Finance and Accounting, 8(2), 128-136

Spencer, L. \& Spencer, S. (1993). Competence at Work: Models for Superior Performance. New York: John Wiley \& Sons, Inc.

Tarmidi, D. \& Waluyo. (2014). Faktor-Faktor yang Mempengaruhi Kepatuhan Pajak, Dengan Pendekatan Perilaku dan Etika (Studi Empiris pada Perusahaan PMA yang Terdaftar di Kanwil DJP Jakarta Khusus). Jurnal TEKUN, V(01), 49-68

Tusubira, F. \& Nkote, I. (2013). Income Tax Compliance among SMEs in Uganda: Taxpayers' Proficiencies Perspectives. International Journal of Business and Social Science, 4(11), 133-143

Tzovas, C. (2006). Factors Influencing a Firms' Accounting Policy Decisions When Tax Accounting and Financial Accounting Coincide. Managerial auditing journal, 21(4), 372-386 
INTERNATIONAL JOURNAL OF ACADEMIC RESEARCH IN BUSINESS AND SOCIAL SCIENCES

Vol. 9, No. 5, May, 2019, E-ISSN: 2222-6990 @ 2019 HRMARS

Unegbu, A. (2014). Theories of Accounting: Evolution \& Developmnets, Income Determninant and Diversities in Use. Research Journal of Finance and Accounting, 5(19), 1-16 